\title{
O governo José Sarney, as canções do rock nacional e a revista Chiclete com Banana
}

\author{
The José Sarney's government, the rock songs and the Chiclete com
}

Banana magazine

Rodrigo Otávio dos Santos*

Resumo: O primeiro presidente da chamada Nova República foi José Sarney. Este artigo tenta contemplar as críticas a este governo feitas pelos jovens artistas que estavam despontando com seus trabalhos no período. Para tanto, destacamos o cartunista Angeli, que naquele momento lançava sua revista Chiclete com Banana e os artistas do chamado rock brasileiro dos anos 1980, principal movimento juvenil do Brasil naqueles anos. O trabalho, então, passa pelos principais momentos do primeiro governo pós-ditadura visto pelos olhos críticos dos principais representantes da juventude, buscando articular o cotidiano vivido pelo povo brasileiro com a verve cômica e ácida do trabalho do quadrinista e dos roqueiros.

Palavras Chave: História do Brasil. História Contemporânea. Economia. Artes

\begin{abstract}
The first president of the called Nova República was José Sarney. This paper try to achieve some critics to this government made for the young artists who was in the first line at that moment. For that, we chose the cartoonist Angeli, who release your magazine called Chiclete com Banana and the artists who played the new rock in Brazil, a movement called Rock Brasil, in the middle of the 1980 decade. This paper also will focus in the major moments in the first government after the military dictatorship, saw by the critic eyes of the musicians and the cartoonist, also trying to articulate the daily life of the Brazilian citizens with the acid critic made by the rock stars and the cartooninst.
\end{abstract}

Keywords: Brazil's History. Contemporary History. Economics. Arts

\footnotetext{
* Doutor em História, atuando no mestrado em educação e novas tecnologias. Programa de PósGraduação em Educação e Novas Tecnologias (PPGENT) no Centro Universitário Internacional Uninter.
} 


\section{Sarney, Brasil, Angeli e o rock nacional.}

O presente artigo tem como finalidade perceber como a sociedade reagia ao governo de José Sarney. Para tanto, nós elencamos duas das grandes fontes culturais do período: as canções do movimento chamado "rock nacional", "rock Brasil" ou "BRock e também as tiras criadas por Arnaldo Angeli Filho na sua revista Chiclete com Banana, de expressiva vendagem entre 1985 e 1990.

$\mathrm{O}$ rock nacional vivia um momento já de grande efervescência. Artistas e grupos como Gang 90 e os Absurdettes, Blitz e Eduardo Dusek estavam em todas as rádios do país e em todas as mentes juvenis ainda no período pré-abertura política, a partir de 1982. Posteriormente mais bandas e artistas integraram este rol, como Barão Vermelho, Os Paralamas do Sucesso, Ultraje a Rigor e muitos outros que destacaremos ao longo deste texto. É importante frisar que na troca do governo militar pelo civil, estes artistas estavam em seu auge de popularidade.

Já o outro foco de nosso trabalho, é a revista Chiclete com Banana. A revista, de acordo com Vergueiro (2014) teve 25 edições ditas bimestrais, entre dezembro de 1985 e dezembro de 1990, ainda que a periodicidade não tenha se mantido estável durante os cinco anos da mais longeva publicação da Circo Editorial. Principalmente no período de grandes traumas econômicos, como lembra o próprio Angeli ${ }^{1}$, a revista não conseguiu seguir a periodicidade esperada. Seu tamanho era o pouco maior que o magazine, medindo 20,5 x $27 \mathrm{~cm}$. Seu conteúdo não era pautado apenas em histórias em quadrinhos, uma vez que havia também fotonovelas, crônicas e sessão de cartas.

O governo de José Sarney começa de forma complexa. Via colégio eleitoral, Tancredo Neves havia derrotado Paulo Maluf no pleito realizado em 15 de janeiro de 1985 e seria o novo presidente do Brasil. Uma semana antes da posse, após algumas viagens, Neves voltou ao Brasil e não se sentia bem. Skidmore (1988) diz que o presidente eleito ocultava um grave problema intestinal com que vinha lutando há meses. Escondia porque imaginava que, se não estivesse bem fisicamente para assumir o planalto, o governo anterior, de João Figueiredo, talvez se valesse desse pretexto para não passar o poder a José Sarney.

$\mathrm{Na}$ véspera da posse Tancredo não aguentou e teve que ser internado às pressas no Hospital de Base de Brasília, para se submeter a uma cirurgia de

${ }^{1}$ Em depoimento no documentário MALDITOS CARTUNISTAS. Direção, Edição e Produção: GARCIA, Daniel \& PAIVA, Daniel. Brasil: Daniéis Entretenimento, 2011. 
emergência. Esperava-se que ele voltasse à ativa em uma semana, mas seu quadro, segundo Pilagallo (2006), deteriorou-se muito rapidamente.

Com o presidente eleito no hospital, Sarney foi empossado e se viu aquém das expectativas dos brasileiros, além de incerto acerca de seus poderes. Um de seus primeiros atos foi instituir, a partir de novembro do ano seguinte, a Assembleia Nacional Constituinte, coincidindo com as eleições legislativas e para governadores. Assim, o Congresso eleito formaria a nova constituição. Além disso, reconhecendo-se como governo provisório, anunciou que não faria uso de recursos autoritários nem de decretos-lei. Entretanto, parcelas da sociedade já indicavam sua desconfiança e descrédito no momento político vivido. Prova disso é a letra da canção Declare Guerra, da banda Barão Vermelho², composta em 1985 e lançada em 1986, que diz $E$ pra te arrasar / Quem te governa não presta / Declare guerra aos que fingem te amar / A vida anda ruim na aldeia / Chega de passar a mão na cabeça / De quem te sacaneia. É interessante perceber, do ponto de vista musical, que a frase quem te governa não presta é cantada em um momento em que todos os demais instrumentos param, deixando o vocal sozinho, evidenciando ainda mais a frase contundente da banda.

Excetuando-se algumas medidas importantes como o fim da censura política e a anistia aos dirigentes sindicais, o governo Sarney estava virtualmente paralisado, acompanhando severamente os boletins médicos sobre a doença do "real" presidente, já que sua doença se prolongava e os brasileiros pareciam cada vez mais preocupados. O governo Sarney se mantinha atento e muito forte graças à percepção de praticamente toda a sociedade brasileira de que o Brasil precisava continuar sua transição para a democracia.

O inevitável, então, ocorreu. Dia 21 de abril de 1985, presidente eleito, sem ter assumido o cargo, Tancredo Neves foi dado como morto, e a comoção nacional pela sua morte tornava ainda mais difícil a tarefa de Sarney. Ele não estava preparado para ser presidente, muito menos para substituir alguém considerado insubstituível por toda uma nação. Sem legitimidade, Sarney se viu obrigado a cumprir de imediato promessas que Neves provavelmente teria deixado para mais tarde.

\footnotetext{
2 Barão Vermelho era uma banda composta inicialmente por Cazuza, Frejat, Guto Goffi, Dé e Maurício Barros. Seu estilo era uma mistura de blues e rock'n' roll, semelhante ao da banda inglesa Rolling Stones. A banda teve seu período áureo entre 1982 e 1984 até que em 1985 o vocalista Cazuza (Agenor de Miranda Araújo Neto, filho do presidente da gravadora Som Livre) decide sair da banda para seguir em carreira solo e o guitarrista Roberto Frejat assume os vocais principais das canções. O disco aqui citado é o primeiro desta fase com Frejat cantando, e um divisor de águas para o grupo.
} 
Skidmore (1988) diz que uma de suas primeiras medidas, no início de maio, foram leis visando a restauração de instituições políticas democráticas. Uma das principais foi o restabelecimento das eleições presidenciais diretas, eliminando o Colégio Eleitoral. Assim, as eleições municipais que escolheriam os prefeitos de 201 cidades, inclusive as 25 capitais, foram marcadas para 15 de novembro de 1985 , sendo a posse fixada para 1 de janeiro de 1986.

Inúmeros candidatos disputaram o pleito, em todo o território nacional. A competição parecia tão caótica, com tantas pessoas buscando a vaga, que até o principal personagem de Angeli, Bob Cuspe, um punk verde e sujo que se alimenta de dejetos e tem como principal meta cuspir nas pessoas, se inscreveu para concorrer à prefeitura, como vemos na imagem abaixo.

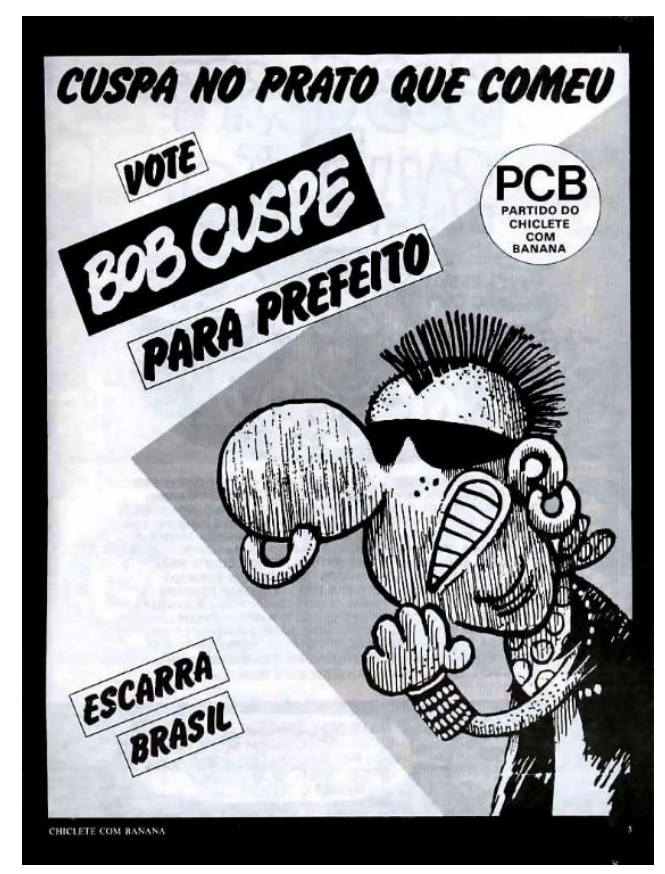

Figura 1. Bob Cuspe para prefeito.

Fonte: Angeli. Chiclete com Banana no 1. São Paulo: Circo, 1985. p.5

Outro problema muito sério a ser enfrentado era a inflação de mais de 300\% ao ano herdada do governo Figueiredo. Pilagallo (2006) diz que a primeira decisão de Sarney foi cortar despesas, e Francisco Dornelles anunciou um corte de 10\% nos gastos públicos, além de outras medidas recessivas. Esta forma de conter a inflação, como sugere Leitão (2010), é ortodoxa, conservadora, e parte da premissa de que a principal causa da inflação é o déficit público, ou seja, a impressão de mais moeda para financiar as contas públicas.

No Brasil havia, ainda segundo a autora, algo chamado conta-movimento. Por ela, o Banco do Brasil trabalhava sem sistema de consolidação, ou seja, as contas não 


\section{Revista Brasileira de História \& Ciências Sociais - RBHCS}

Vol. $8 \mathrm{~N}^{\circ}$ 16, Julho - Dezembro de 2016

fechavam durante o dia e o Banco do Brasil mandava o Banco Central imprimir mais moeda para tapar o rombo diário. Graças a este recurso, o maior banco do país poderia ter a administração descuidada que tivesse, pois sempre haveria moeda para sustentar as extravagâncias governamentais. Essa conta sem lastro ajudou sobremaneira a criação e permanência da inflação brasileira.

Outro problema econômico, apontado por Skidmore (1988) era a dívida externa. No momento da posse de Sarney, era a maior dívida do mundo, e a imprensa europeia e norte-americana constantemente advertiam que uma inadimplência mexicana ou brasileira poderia desencadear o colapso do sistema bancário mundial. Os economistas afirmam que, em países em desenvolvimento, existe uma prática de políticas desprovidas de solidez financeira, e que a classe política procura atender às necessidades imediatas da população, favorecendo o consumo e não os investimentos, prejudicando assim o desenvolvimento futuro.

Mesmo tendo inflação no período militar, o país apresentava taxas de crescimento anuais em torno de $9 \%$, neutralizando a inflação e promovendo o crescimento. O problema é que, quando ela chega aos três dígitos sérias distorções começam a ocorrer, como o poder de compra dos salários, que, em seis meses entre um reajuste e outro, é muito penalizado, chegando no final dos seis meses a comprar metade do que conseguia no início do reajuste. Isso causava perdas reais para os trabalhadores.

Antes de assumir a presidência, Tancredo Neves e Francisco Dornelles já haviam colocado a inflação como problema número um a ser enfrentado. Quando Dornelles tentou conter a inflação e não conseguiu com os meios ortodoxos, pediu demissão. Neste período, Léo Jaime3, com muita irreverência e duplo sentido, compôs e lançou a canção $O$ Regime, onde canta: a barriga cresce junto com a inflação / O problema é o regime / Que não dá satisfação.

Em agosto de 1985 Dilson Funaro assume como novo Ministro da Fazenda, e junto com o Ministro do Planejamento, João Sayad, começaram a tentar elaborar uma nova estratégia macroeconômica. Um sinal otimista era que o governo Sarney herdara de Figueiredo uma economia de franca aceleração. O PIB de 1985 subiu 8,3\%

\footnotetext{
3 Léo Jaime era um cantor goiano, que foi para o Rio de Janeiro tentar a sorte como artista. Antes de dedicar-se à carreira solo, integrou brevemente o Barão Vermelho e João Penca e Seus Miquinhos Amestrados, banda que fez muito sucesso comercial na década de 1980. Seu estilo musical era uma espécie de resgate das baladas rock'n'roll norte-americanas dos anos 1950, de artistas como Little Richard ou Jerry Lee Lewis.
} 


\section{Revista Brasileira de História \& Ciências Sociais - RBHCS}

Vol. $8 \mathrm{~N}^{\mathrm{o}}$ 16, Julho - Dezembro de 2016

tornando o Brasil o país com o crescimento mais alto do mundo naquele ano. $\mathrm{O}$ problema é que este boom gerava inflação.

Como consequência, a popularidade do presidente José Sarney caía na mesma medida que a inflação subia. O bolso do brasileiro parecia ser a melhor medida de rejeição ou apoio ao governo. Skidmore (1988) diz que a imprensa clamava de forma unânime por mais rigorosas medidas contra a inflação, e até a reforma ministerial foi esquecida. Uma das canções compostas neste período pela banda paulista Titãs 4 traduzia singularmente este sentimento de indignação com o governo e o aumento da inflação. A canção Dívidas diz: Meu salário desvalorizou / Dividas, juros, dividendos / Credores, credores, credores / Agora é assim / Senhores, senhores, senhores / Tenham pena de mim / Contas, recibos, impostos.

Em vista de tamanha crise por conta da inflação, o ministro Dilson Funaro ofereceu a Sarney um plano de "choque heterodoxo" para parar com a inflação. Anos antes, André Lara Resende e Pérsio Arida, dois economistas renomados e que estavam na PUC-RJ naquele momento que, em parceria, criaram o texto mais importante da nova ideia de combate à inflação: o Plano Larida, de 1983. Este plano, cujo nome derivava da junção dos nomes de seus criadores, tentava explicar e agir contra uma inflação resistente às teorias tradicionais.

De acordo com Arida e Resende (1986), havia três pilares no plano: reforma monetária, indexação total e choque heterodoxo. Esse plano, alterado por motivos políticos e populistas foi utilizado por Sarney e Funaro. O Larida sustentava que a natureza da inflação brasileira era diferente daquela apontada pelo FMI. Era inercial. Ou seja, os bens aumentavam de valor simplesmente porque no mês anterior havia aumentado, fazendo da inflação passada o melhor indicador da inflação futura. Todos os contratos da economia, preços e tarifas eram corrigidos em intervalos regulares, criando uma inércia. Só que a inflação aumentava quando havia algum problema pontual na economia, como quebra de safra, alta do petróleo, e quanto mais subia, mais pressão havia para que as correções fossem feitas em prazos menores. E, ao corrigir tão rápido, gerava mais inflação.

O plano de Resende e Arida era promover uma ruptura na velha ordem. No plano original havia a ideia de criar uma nova moeda, o Novo Cruzeiro (NC), fazendo

\footnotetext{
4 A banda Titãs foi formada por ex-alunos do Colégio Equipe, um dos redutos da intelectualidade paulistana. Mesmo sem saber tocar em seu início, os músicos se desenvolveram e conseguiram com o álbum Cabeça Dinossauro seu maior trunfo tanto de público quanto de crítica.
} 


\section{Revista Brasileira de História \& Ciências Sociais - RBHCS}

Vol. $8 \mathrm{~N}^{\mathrm{O}}$ 16, Julho - Dezembro de 2016

uma reforma monetária para introduzi-la. Este novo numerário seria inicialmente um indexador de alcance geral indexado e corrigido diariamente. Assim, com esta proposta, gradual e lentamente todos os depósitos bancários, contratos e preços seriam convertidos para este novo indexador. Quando a adesão fosse total ou quase total, este indexador seria convertido na nova moeda. Ainda de acordo com Resende e Arida (1986), neste plano, o cruzeiro continuaria existindo em sua trajetória inflacionária e perderia valor diariamente diante do indexador geral que seria o NC. Naturalmente, segundo os criadores do plano, a economia escolheria a novo indexador e abandonaria os antigos. Havia ainda a ideia do economista Chico Lopes, que achava que a ruptura deveria vir com o congelamento dos preços por um tempo determinado, para que as pessoas apagassem de suas mentes a ideia da remarcação de preços e consequente inflação. Seria uma outra forma de romper a inércia inflacionária.

Assim, o projeto era criar uma moeda virtual indexada e fazer uma lenta conversão, com a convivência - durante determinado tempo - das duas moedas na economia. Sarney e seus correligionários, porém, não tinham esse tempo e também achavam aquilo complicado demais, principalmente em um momento de tamanha fragilidade política. A inflação já batia os 360\% ao ano e continuava aumentando. Segundo Pilagallo (2006), em janeiro a projeção anual estava em 500\%. Assim, mesmo sem ter o plano completamente formado, Sarney anunciou a data para seus técnicos: 28 de fevereiro de 1986.

Até a última hora, decisões importantes ainda não tinham sido tomadas. Foi apenas na reta final que o pacote tomou forma definitiva, em uma tentativa de fazer o que os economistas apontavam como o correto, mas também tendo um aproveitamento político com viés muito calcado no populismo. Entre as características populistas que mais incomodavam os economistas estavam o abono salarial e o congelamento de preços por tempo indeterminado. Estas características e algumas outras demandadas diretamente da presidência - políticas e não técnicas levaram à derrocada do plano, como veremos.

Skidmore (1998) enumera as principais características do plano: o moeda Cruzeiro seria substituída, na proporção de 1000 para 1 por outra moeda, o Cruzado; A indexação seria abolida; os preços seriam congelados por tempo indeterminado; o salário mínimo seria reajustado pelo seu valor médio nos últimos seis meses, mais um abono de $8 \%$ e os reajustes posteriores seriam automáticos sempre que a inflação 


\section{Revista Brasileira de História \& Ciências Sociais - RBHCS}

Vol. $8 \mathrm{~N}^{\circ}$ 16, Julho - Dezembro de 2016

chegasse aos 20\%, ou seja, um gatilho salarial; os trabalhadores teriam liberdade de negociar com seus empregadores aumentos adicionais de salário; criação do segurodesemprego; mudança na política cambial: a partir desse momento o Banco Central decidiria quando e quanto desvalorizar a moeda.

O plano obteve apoio imediato de uma população machucada pela inflação. Pilagallo (2006) conta que donas de casa viraram "fiscais do Sarney", denunciando remarcações de preços, e a inflação diminuiu na mesma proporção que aumentou a popularidade do presidente. Sardenberg em entrevista à Stefanelli (2002) diz que nunca o país viu um presidente com tamanha popularidade. Em algumas pesquisas o presidente tinha mais de $90 \%$ de apoio popular. Índice nunca mais alcançado por nenhum outro estadista. Como o plano agregava também uma certa ambição progressista e de justiça social e redistribuição de renda, Skidmore (1998) diz que Sarney e Funaro viraram heróis nacionais.

$\mathrm{Na}$ primeira medição pós-plano, a inflação estava controlada em cerca de $3,38 \%$, entre março e maio de 1986 . Os preços não aumentavam e quando algum comerciante tentava fazê-lo, logo era barrado pelos autoproclamados fiscais do presidente. Isso gerava alguns problemas, como o fato do órgão controlador de preços, SUNAB, não poder atender a demanda de tantas queixas. Leitão (2010) comenta que em alguns casos pessoas comuns instituídas do suposto poder delegado por Sarney fecharam as portas de alguns estabelecimentos à força. Os consumidores estavam maravilhados com sua capacidade de compra, e seu comportamento mudou, aumentando o consumo exageradamente no país. Naquele momento era social e politicamente impossível ir contra o Plano Cruzado.

Com os preços congelados e aumento real dos salários, Skidmore (1998) diz que houve uma orgia de compras. Isso porque as pessoas, não acostumadas à falta de inflação, imaginavam que deveriam comprar os produtos e estocá-los, enquanto o preço ainda estava barato. Com isso os produtos, de forma geral, começaram a sumir das prateleiras. Leitão (2010) sugere que, em parte, isso ocorreu porque a economia era muito cartelizada, e a maioria dos produtos era controlada por dois ou três fabricantes, sendo comum também o monopólio privado.

Como as pessoas compravam tudo o que viam pela frente a fim de estocar ou de aproveitar, os produtos começaram a faltar, pois não havia produção suficiente no país para tamanha demanda. Até o índice de preços começou a ficar falho, porque alguns produtos simplesmente não eram encontrados nos supermercados. Com isso 


\section{Revista Brasileira de História \& Ciências Sociais - RBHCS}

Vol. $8 \mathrm{~N}^{\circ}$ 16, Julho - Dezembro de 2016

veio o ágio. Produtores deixavam os produtos acabarem e não repunham nos mercados. Quem quisesse comprá-los teria que pagar uma taxa a mais. Mesmo sendo ilegal, as pessoas se sujeitavam a esta prática, pois os produtos que faltavam não eram apenas os supérfluos. Eram gêneros de primeira necessidade, como carne, leite ou ovos.

Os brasileiros estavam vivendo em filas. Talvez a canção rock que mais explicite este momento da sociedade brasileira seja Perplexo, sucesso da banda carioca Paralamas do Sucesso5. Além do título da canção que faz alusão ao momento histórico, temos versos como Desempregado, despejado, sem ter onde cair morto / Endividado sem ter mais com que pagar / Nesse país, nesse país, nesse país / Que alguém te disse que era nosso / Há, há, há / Mandaram avisar / Que agora tudo mudou / Eu quis acreditar / Outra mudança chegou / Fìm da censura, do dinheiro, muda nome, corta zero / Entra na fila de outra fila pra pagar.

Além disso, como informa Skidmore (1998), em junho os empréstimos a longo prazo ainda não haviam recomeçado. Como a indexação foi extinta, o emprestador ficou sem proteção, o que fez com que ele reduzisse a concessão de empréstimos necessários para financiar os investimentos e, consequentemente, o crescimento econômico. Além disso, graças à incerteza no mercado financeiro, o ágio do dólar paralelo disparou. Neste mesmo mês a moeda norte-americana era vendida no câmbio paralelo 52\% mais cara do que o oficial. Ao final do Plano Cruzado, a banda Camisa de Vênus 6 criou a canção País do Futuro, lançada apenas em 1987, e que continha versos que demonstravam como enxergavam a situação naquele momento econômico do país, como o abono salarial, a inflação galopante e o gatilho salarial. Alguns de seus versos eram Aqui não tem problema, só se você quiser / Este é o país do futuro, tenha esperança e fé / (...) / Vai ficar tudo bem, acredite em mim, meu filho / A gente aumenta o seu salário, dispara o gatilho / Aí, pra que você não reclame, e também pra que não esqueça / Dispararam o tal do gatilho, em cima da sua cabeça / Nós vamos outra vez, pro fundo do buraco.

\footnotetext{
5 Paralamas do sucesso é uma banda carioca, formada pelos músicos Hebert Vianna, Bi Ribeiro e João Barone. Foi um dos maiores expoentes do movimento do rock nacional e tinha como principal característica a tentativa de fusão dos ritmos norte-americano e inglês do rock'n'roll com ritmos caribenhos e brasileiros. Foi a banda brasileira de maior projeção na América Latina e continua na ativa até os dias atuais.

${ }^{6}$ Camisa de Vênus foi uma banda baiana formada em 1980 cujo estilo assemelhava-se ao punk rock, principalmente no que tange às vestimentas e as letras, sempre denuncistas, debochadas e cínicas. $\mathrm{E}$ mesmo com pouca visibilidade em rádio, dado o conteúdo das letras, teve grande vendagem no país.
} 


\section{Revista Brasileira de História \& Ciências Sociais - RBHCS}

Vol. $8 \mathrm{~N}^{\mathrm{o}}$ 16, Julho - Dezembro de 2016

Pilagallo (2006) diz que os economistas advertiram Sarney para a gravidade da situação e sugeriram uma correção de rumo, adotando medidas para refrear o consumo. Sarney, porém, não queria colocar em risco sua popularidade e a do governo em um momento tão próximo das eleições, que seriam realizadas em novembro. Nestas eleições o eleitor conhecia muito de seus candidatos a partir do Horário Eleitoral Gratuito, peças publicitárias de partidos e candidatos que eram veiculadas diariamente em todos os canais de televisão e rádio simultaneamente, não deixando opção de programação para os espectadores. Como eram muitos os candidatos, vários deles tentavam um lugar ao sol utilizando-se de expedientes estranhos a políticos ou à televisão. Além dos programas bem feitos, com candidatos preparados para a televisão, havia também os mal feitos, programas cujos candidatos não sabiam falar em frente à câmera, não conseguiam explicar suas propostas, tinham dificuldades de roteiro e vários deles careciam seriamente de orçamento. Além disso, alguns candidatos recorriam à bizarrice como forma de chamar a atenção do eleitorado, com propostas absurdas, temas estranhos à política, depoimento da família ou de artistas e até mesmo vestimentas chamativas. Para criticar candidatos, partidos e programas de governo, Angeli fez a seguinte história em quadrinhos: 
Revista Brasileira de História \& Ciências Sociais - RBHCS

Vol. $8 \mathrm{~N}^{\circ}$ 16, Julho - Dezembro de 2016

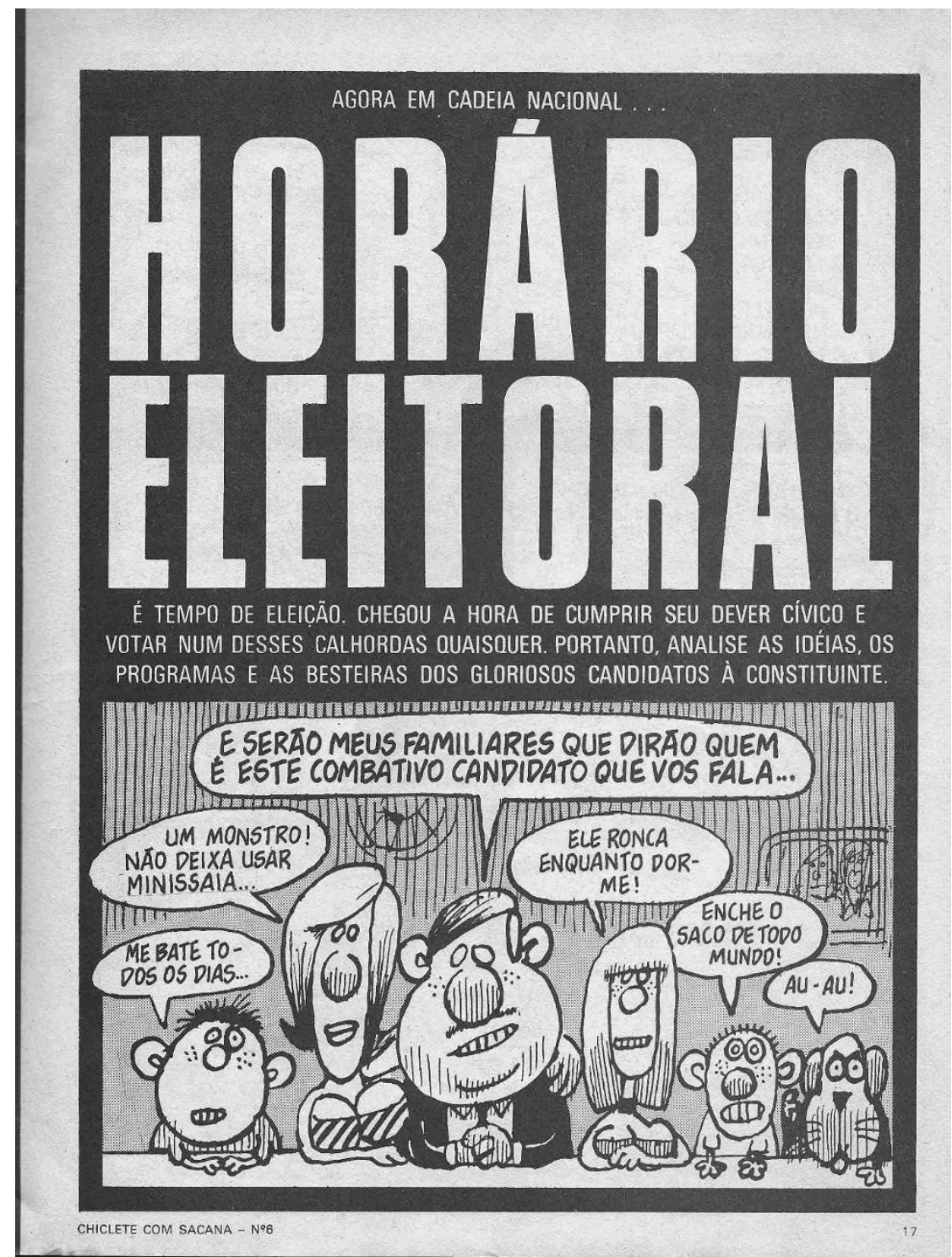

Figura 2. Horário Eleitoral Gratuito (1).

Fonte: Angeli. Chiclete com Banana no 6. São Paulo: Circo, 1986. p.17 
Revista Brasileira de História \& Ciências Sociais - RBHCS

Vol. $8 \mathrm{~N}^{\mathrm{O}}$ 16, Julho - Dezembro de 2016

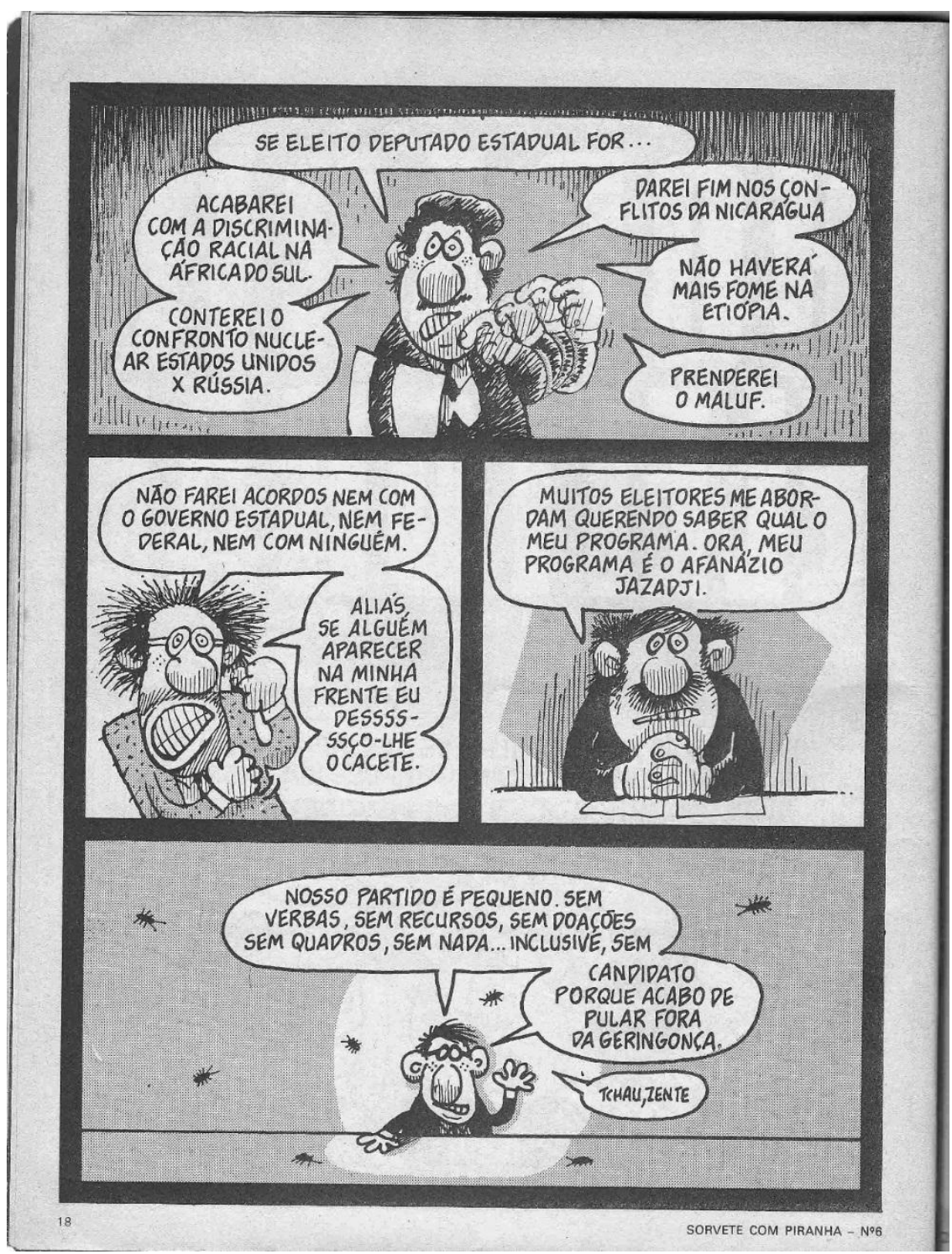

Figura 3. Horário Eleitoral Gratuito (2).

Fonte: Angeli. Chiclete com Banana no 6. São Paulo: Circo, 1986. p.18 


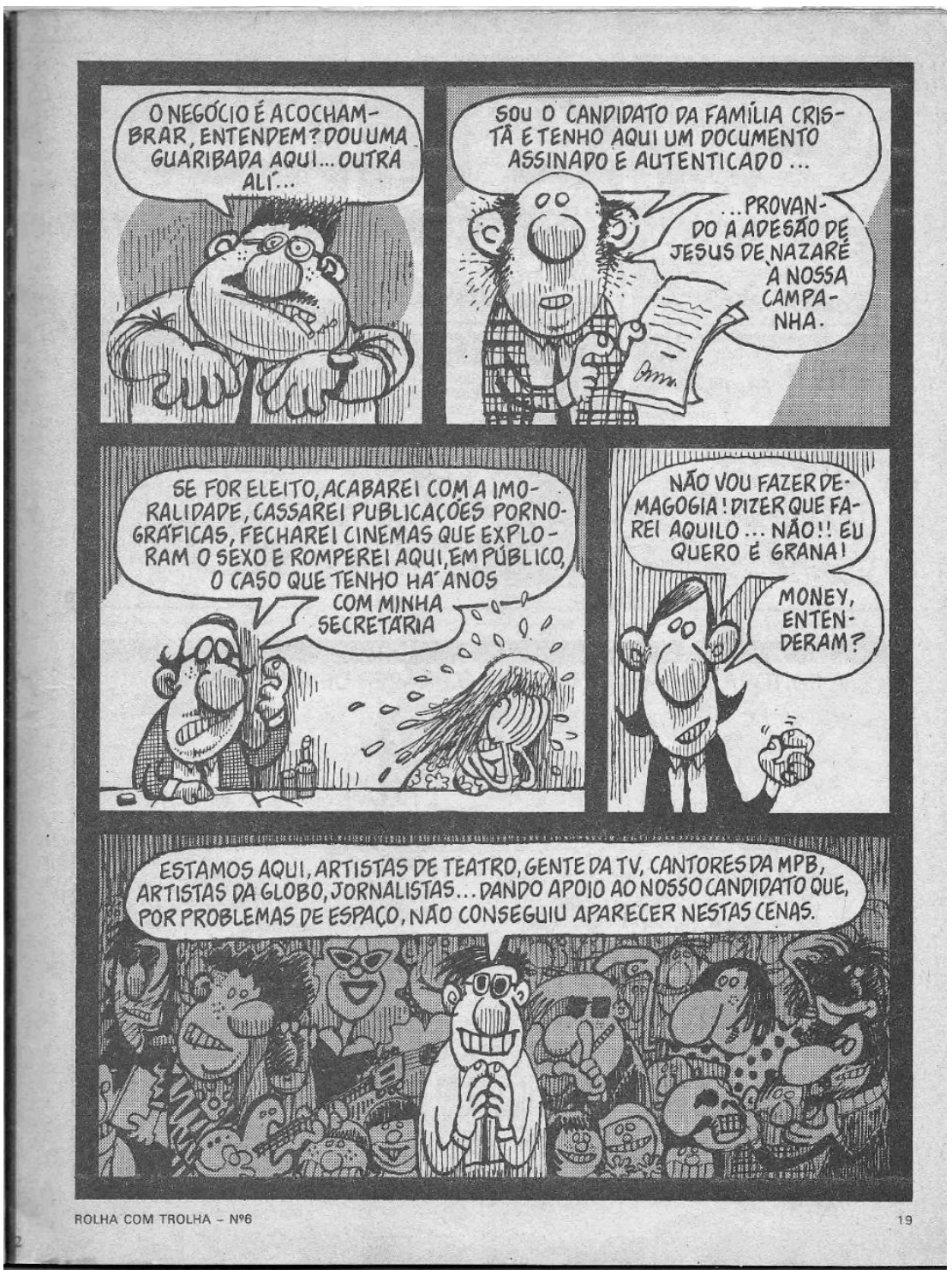

Figura 4. Horário Eleitoral Gratuito (3).

Fonte: Angeli. Chiclete com Banana no 6. São Paulo: Circo, 1986. p.19

Esta história em quadrinhos mostra a descrença nos partidos políticos do período e até mesmo um descrédito em relação à própria democracia. Souza (1988) explica que sob o ponto de vista dos políticos, a Nova República não era tão diferente do governo militar, principalmente porque as pessoas, os políticos, eram os mesmos. Os militares brasileiros saíram dos quartéis e foram para o congresso. Daí a piada em relação à austeridade e hipocrisia do primeiro candidato. O segundo candidato é uma caricatura dos candidatos que prometiam, àquela altura, medidas inalcançáveis. Ao mesmo tempo, é uma indicação da indignação de certa parcela da sociedade em relação a Paulo Maluf. A radicalização de alguns partidos e sua forma de se apresentar ao público foi criticada no terceiro quadrinho. No quarto quadrinho, Angeli critica a corrupção e a facilidade que os políticos têm de desviar verbas 


\section{Revista Brasileira de História \& Ciências Sociais - RBHCS}

Vol. $8 \mathrm{~N}^{\circ}$ 16, Julho - Dezembro de 2016

governamentais. O próximo quadrinho fala sobre os partidos minúsculos, deixando claro que estes não têm condições de lutar por vagas no congresso e no senado.

Na página seguinte, Angeli mostra o candidato que não tem suporte político, mas diz ao povo que vai fazer mudanças sociais na base da malandragem, eticamente condenável. A bancada cristã está representada no sétimo quadrinho. Usualmente estes eleitores votam em candidatos que professam a mesma fé, independentemente de sua plataforma governamental. Novamente a hipocrisia é atacada no oitavo quadrinho, onde o personagem se diz o bastião da moralidade e, contraditoriamente, tem um caso com sua secretaria há anos. O próximo candidato reflete a visão de muitas pessoas em relação à política como um todo, ou seja, que os políticos estão lá para governar em benefício próprio, ignorando o povo e seus eleitores.

Por último, a força da mídia se mostra. O candidato não coube no horário eleitoral porque havia personalidades demais em seu programa. Souza (1988) diz que boa parte do imaginário acerca da política e dos políticos foi construído pelos meios de comunicação, e que a desconfiança arraigada em relação a estes atores acabou por forjar uma descrença generalizada sobre a classe política no país. A autora continua explicando que, naquele momento, pela primeira vez se votaria sem o jugo militar, a própria percepção do processo político por parte da sociedade brasileira era fugidia. O pleito eleitoral realizar-se-ia com uma sociedade ainda pouco amadurecida neste sentido.

Com o congelamento de preços mantido, a população compareceu às urnas achando o presidente o salvador da pátria. Foi a maior vitória do PMDB em todos os seus anos de história. O partido ganhou em todos os Estados do Brasil menos Sergipe e obteve grande maioria tanto na Câmara quanto no Senado, dominando um Congresso que iria escrever a nova Constituição Federal, ainda que a maioria dos votantes fossem oriundos do Arena.

No dia seguinte às eleições veio o Plano Cruzado II, elaborado pelo assessor de Funaro, João Manoel Cardoso de Melo, daí o apelido do plano no interior do governo: Manoelaço. Com este novo plano, acabava o congelamento de preços, os alugueis estavam liberados do controle do governo, aumentavam os impostos sobre bebidas e cigarros, as tarifas de serviços públicos e aumentava a carga fiscal. O plano pretendia controlar o déficit fiscal e aumentar a receita tributária. Dória (2012) diz que no dia seguinte ao plano a gasolina aumentou 60\%, energia e telecomunicações aumentaram 120\%, as bebidas 100\%, os automóveis 80\% e cigarros 100\%. O povo, 


\section{Revista Brasileira de História \& Ciências Sociais - RBHCS}

Vol. $8 \mathrm{~N}^{\mathrm{o}}$ 16, Julho - Dezembro de 2016

entretanto, não estava esperando tamanho aumento e tampouco esperavam que fosse feito dessa forma, como uma manobra eleitoreira. No dia 21 de novembro de 1986 houve manifestações em Brasília, episódio que ficou conhecido como Badernaço. No dia 27 houve saques, incêndios e depredações. Além disso, o que o governo não previu foi que as pessoas ainda persistiam com sua memória inflacionária e, ao liberar os preços, alimentou novamente o desejo dos produtores e vendedores de aumentar seus preços, gerando mais inflação. A inflação foi de 3\% em novembro, 7\% em dezembro e $16 \%$ em janeiro de 1987. Neste momento, a banda Titãs cria sua canção Desordem, que retrata o momento com os versos A multidão enfurecida / Queimou os carros da polícia. / Os preços fogem do controle, / Mas que loucura esta nação! / Não é tentar o suicídio / Querer andar na contramão? / (...) / Mas o que é criar desordem, / Quem é que diz o que é ou não? / São sempre os mesmos governantes, / Os mesmos que lucraram antes. / Os sindicatos fazem greve / Porque ninguém é consultado, / Pois tudo tem que virar óleo / Pra por na máquina do estado.

Em fevereiro de 1987, depois de ficar claro que o Plano Cruzado II já estava fracassando, Dilson Funaro decide aplicar a moratória nos bancos credores e parar de pagar os juros da dívida externa. Isso, para Sardenberg (em entrevista a Stefanelli (2002)), não foi moratória. Foi um calote. Por mais que Sarney, em rede televisiva para todo país, tenha dito que era uma questão de soberania nacional, na verdade era simplesmente o fato de o país não ter mais como pagar suas dívidas. Assim, Sarney simplesmente avisou que não iria pagar. Pilagallo (2006) resume a questão dizendo que Sarney fez a moratória parecer um enfrentamento, porém ela não era uma opção. A moratória era falta de opção. O discurso à nação, em cadeia nacional, não passou incólume pelo traço de Angeli, que colocou Sarney mais de uma vez como um indivíduo que não sabia exatamente o que fazer. 


\section{Revista Brasileira de História \& Ciências Sociais - RBHCS}

Vol. $8 \mathrm{~N}^{\mathrm{o}}$ 16, Julho - Dezembro de 2016

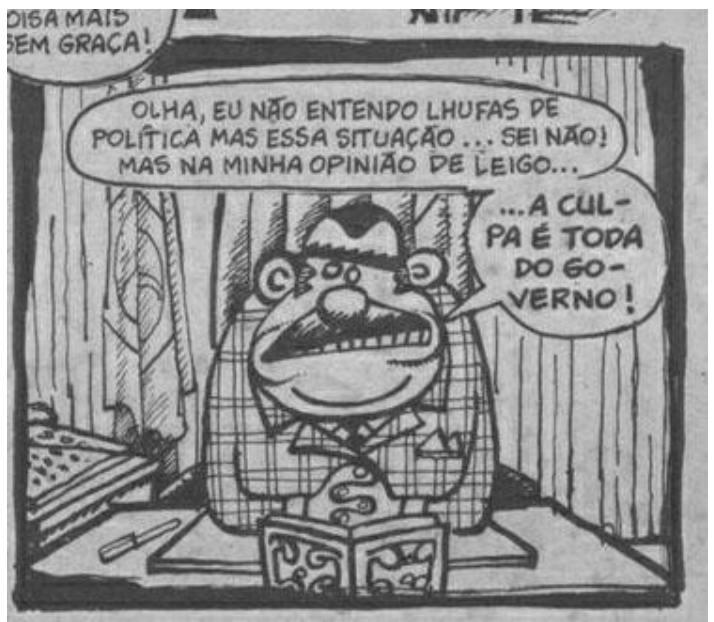

Figura 5. Pronunciamento à nação.

Fonte: Angeli. Chiclete com Banana no 13. São Paulo: Circo, 1988. p.4

Moraes (1990) explica que o consumo exacerbado do país tinha provocado déficits comerciais crescentes. As reservas cambiais se extinguiram. Havia um volume oficial de 2,3 bilhões de dólares apenas e nem tudo tinha liquidez. A moratória foi apontada como golpe de marketing, porque na verdade o país não tinha dólares nem para pagar as importações essenciais. E a economia colapsou-se. Os preços subiam absurdamente, a produção estava desorganizada, porque não sabia o real estado financeiro de seus possíveis compradores, as reservas estavam esgotadas e não havia dinheiro para importar matérias-primas. Neste período, em seu disco gravado ao vivo Viva!, o Camisa de Vênus lança a canção Solução Final, que diz A situação está insustentável / mas temos que seguir em frente / Compre dólares no câmbio negro / e vamos celebrar a grandeza do ocidente. Dilson Funaro foi demitido em maio de 1987. Ulysses Guimarães, então presidente do PMDB e da Câmara, fez uma intervenção direta e colocou Luiz Carlos Bresser Pereira como Ministro da Fazenda.

O Plano Bresser foi anunciado dia 12 de junho. O próprio Bresser em entrevista a Stefanelli (2002), explicou que era um plano transitório. Primeiro haveria um plano de contenção para depois de alguns meses conseguir fazer um real plano econômico que levasse o país novamente ao crescimento. Neste plano, instituiu-se novo congelamento de preços e salários, desta vez, por apenas 90 dias. Além disso, criou-se a Unidade de Referência de Preços (URP), para servir como referência monetária para reajuste de preços e salários.

O plano teve vida curta, pois três meses depois a inflação já estava em dois dígitos novamente. Um dos principais fatores do fracasso foi a postura dos empresários, que como estavam assustados ainda com as perdas oriundas do Plano Cruzado, imaginaram que poderia haver um congelamento de preços e ato contínuo 


\section{Revista Brasileira de História \& Ciências Sociais - RBHCS}

Vol. $8 \mathrm{~N}^{\mathrm{O}}$ 16, Julho - Dezembro de 2016

decidiram remarcar preventivamente seus preços para níveis muito maiores do que aqueles anteriores ao plano. Bresser Pereira não se manteve no cargo para o ano seguinte. Foi demitido em 21 de dezembro de 1987. O secretário-geral do ministério, Maílson da Nóbrega, foi escolhido como interino.

Além da parte econômica, 1987 foi o ano em que o Brasil viveu a Constituinte. Após 20 anos sob o jugo militar, os brasileiros julgavam que todo o mal era fruto do trabalho que os militares haviam feito no governo. Portanto, agora bastava vontade política para incluir na constituição tudo aquilo que os brasileiros precisavam. Mas o jogo político não é tão simplista, e o povo também não o é, então várias forças políticas jogavam para tentar criar uma carta-magna que acolhesse os desejos do povo. Mas também os desejos individuais de cada área ou grupo político. Além disso, de acordo com Sola (1995), na Constituição havia sucessivas oportunidades de alteração das regras do jogo, caso necessário fosse, além de postergar uma série de decisões para depois da promulgação. Para ironizar os deputados e senadores envolvidos no processo da nova constituição, Angeli criou a página abaixo, que satiriza o estereótipo do político ao mesmo tempo que mordazmente conduz o leitor a imaginar o que estas pessoas fazem no suposto exercício de seus deveres. A descrença com a democracia é aqui explicitada, tal qual anunciada por Souza (1988). Políticos aos olhos da população não trabalham ou, se trabalham, o fazem em benefício próprio, nunca a favor da população que o elegeu. Os políticos são, como coloca a autora, desqualificados pela população, bem como todo o processo da construção da nova Carta Magna brasileira. 

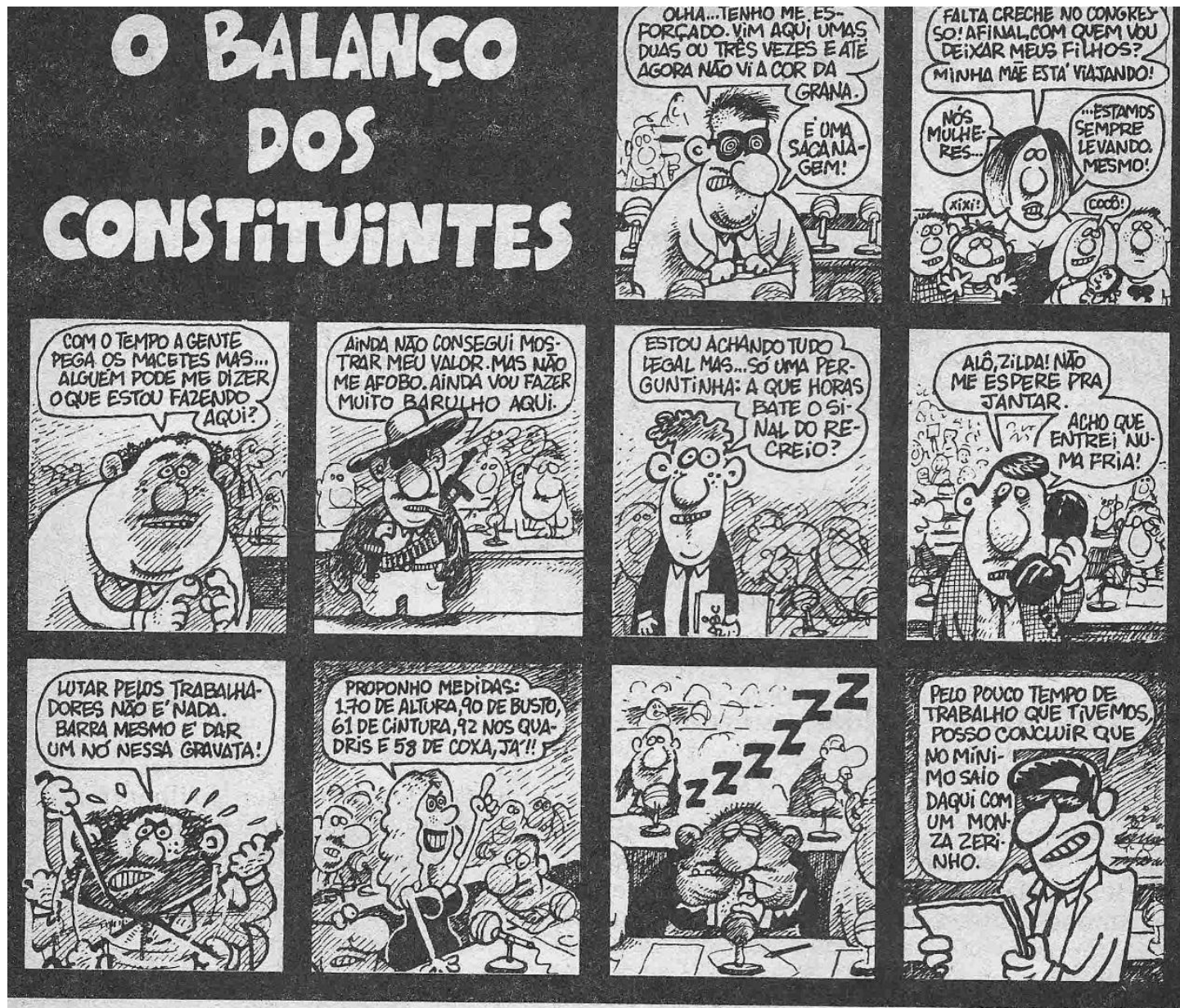

Figura 6. Balanço dos constituintes.

Fonte: Angeli. Chiclete com Banana no 11. São Paulo: Circo, 1987• p.23

Além de Angeli, outras críticas foram feitas à constituinte. A mais satírica e contundente veio da banda Ultraje à Rigor7, que em seu disco Crescendo colocou a música A Constituinte, “composta” em 1987 e lançada em 1989, e que revela a canção infantil Atirei o pau no gato, deixando claro que não levavam, assim como boa parte da sociedade, a constituinte e seus parlamentares a sério.

Como foi produto de concessões a segmentos da sociedade com interesses conflitantes, a Carta Magna do país foi criticada por muitos, inclusive os lados radicais. Angeli não se eximiu das críticas e criou a sua versão do político brasileiro. Com a cara do animal semelhante à caricatura de Paulo Maluf, o artista criou a seguinte página:

\footnotetext{
7 Ultraje a Rigor é um grupo de rock paulista cuja principal característica está na comicidade das letras. A ironia e uma crítica mordaz da sociedade estão presentes em praticamente todas as letras do grupo na década de 1980.
} 


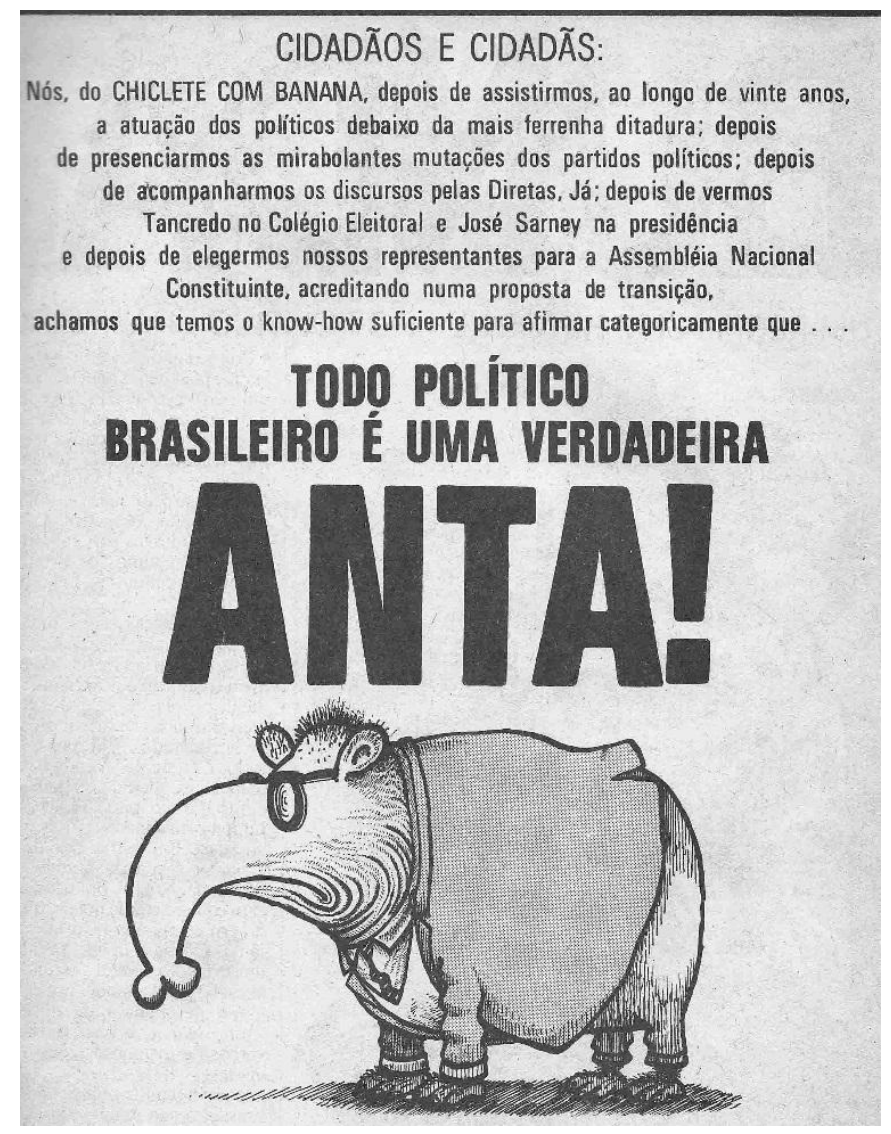

Figura 7. Político anta.

Fonte: Angeli. Chiclete com Banana no 11. São Paulo: Circo, 1987. p.5

Com esta página Angeli deixa claro seu desencanto com a proposta de transição da política brasileira, e mesmo com a própria constituição que estava sendo forjada naquele momento. Mesmo desencanto que levou a banda Legião Urbana ${ }^{8}$ a lançar a canção Que país é este?, no álbum de mesmo nome e que em sua letra dizia Nas favelas, no senado / Sujeira pra todo lado / Ninguém respeita a constituição / Mas todos acreditam / no futuro da nação / Que país é este? Evidenciando a descrença de uma parte da população em relação à nova carta que regeria o Brasil. Sola (1995) diz que a constituição foi uma conquista ambígua, sendo obstáculo para diversas manobras governamentais de combate à inflação por um lado, e promovendo conquistas sociais inéditas na história brasileira por outro lado.

Ao mesmo tempo, a inflação piorava a vida dos brasileiros e em 1988 tivemos o fenômeno da estagflação, ou seja: estagnação somada à inflação. E depois de dois choques heterodoxos fracassados, o país começou a ter medo de qualquer novidade.

\footnotetext{
8 Legião Urbana foi uma das mais influentes bandas da geração do rock anos 1980 no Brasil. Liderada por Renato Russo, nos três primeiros discos eram tinham uma sonoridade mais próxima ao punk, com três acordes básicos produzindo toda a canção. Do ponto de vista das letras, denúncias e angústias próprias dos jovens recém-saídos do regime militar.
} 
Leitão (2010) diz que este foi o mote para a criação do modelo "feijão com arroz" de Maílson da Nobrega. Por esse pressuposto, não haveria planos emergenciais, o Brasil deveria apenas seguir os preceitos do FMI para manter uma performance saudável para o país. Não deu certo e a inflação cresceu ainda mais, fazendo com que os brasileiros e a imprensa imaginassem um novo plano econômico surgindo.

E ele foi apresentado no domingo, 15 de janeiro e foi chamado de Plano Verão, que durou menos que um verão. Em março quando a inflação foi anunciada em $6 \%$ o ministro já sabia que havia fracassado. Logo em seguida a inflação voltou aos dois dígitos e, nos próximos 11 meses a economia do país descontrolou-se.

A inflação estava chegando a mais de 50\% ao mês e a palavra hiperinflação já era comum nos noticiários. Muitos lembravam a Alemanha e sua hiperinflação no entre-guerras9. Os preços subiam diariamente e a pior coisa que um brasileiro poderia fazer era ficar com dinheiro em casa, sendo que aquele ano terminou com 1782\% de inflação. Além disso, a dívida pública praticamente dobrava a cada mês.

O presidente Sarney estava com sua popularidade muito negativa. Souza (1988) diz que, em março de 1988, 62,7\% da população brasileira queria Sarney fora do Planalto.

O cantor e compositor Lobão ${ }^{10}$ fez sucesso com a canção $O$ eleito, que em sua letra faz várias críticas ao presidente, tais como Ele é esperto e persistente / Acha que nasceu pra ser respeitado / Ele é incerto e reticente / Acha que nasceu pra ser venerado / (...) / Seus ternos são bem cortados / Seus versos são mal escritos / Seus gestos são mal estudados / A sua pose é militarista / Ele se acha o intocável / Senhor de todas as cadeiras / Derruba tudo pra ficar estável / (...) / E tudo parece estar errado / Mas nesse caso o erro deu certo / Foi o que ele disse ao pé do rádio / Com a honestidade pelo avesso. Interessante perceber a crítica mordaz, que não se preocupa em utilizar artifícios para a mensagem ficar codificada: ela é explícita ao ouvinte da canção. E até mesmo a referência ao programa semanal do presidente é

\footnotetext{
9A Alemanha depois da Primeira Guerra Mundial sofreu uma das maiores hiperinflações do mundo. A obrigação de pagar fortes indenizações às nações vencedoras e a caótica situação interna que impedia obter pela via fiscal os ingressos necessários, induziram a República de Weimar a financiar-se imprimindo papel moeda sem nenhuma contenção. Em dois anos, entre janeiro de 1922 e dezembro de 1923 a taxa acumulada de inflação ascendeu a um bilhão por cento.

${ }^{10}$ João Luiz Woerdenbag Filho, mais conhecido como Lobão, foi o primeiro baterista da seminal banda de rock progressivo Vímana. Mais tarde, tornou-se baterista da banda Blitz, um dos maiores expoentes do chamado rock brasileiro. Ainda antes de gravar o primeiro LP, Lobão saiu da banda e tentou uma carreira solo, primeiramente cantando e tocando guitarra acompanhado d'Os Ronaldos e mais tarde apenas como Lobão.
} 


\section{Revista Brasileira de História \& Ciências Sociais - RBHCS}

Vol. $8 \mathrm{~N}^{\mathrm{O}}$ 16, Julho - Dezembro de 2016

bem explícita. Se o artista não coloca o nome e o cargo do personagem de sua canção, a alusão ao "pé do rádio" explicita de quem Lobão está falando, isto porque Entre outubro de 1985 a março de 1990, toda sexta-feira, pela manhã, o então presidente José Sarney tinha um programa de rádio intitulado Conversa ao pé do rádio.

Sarney se tornou o pior cabo eleitoral possível nas eleições de 1989. Sendo a primeira eleição presidencial desde 1960, crucificar Sarney era certeza de apreciação do eleitorado. E, em apoio à hipótese, os dois candidatos que mais criticaram o presidente foram para o segundo turno: Lula e Collor, sendo que este último acabou sagrando-se o próximo presidente brasileiro.

Ao fim e ao cabo, o governo de José Sarney foi uma grande etapa na redemocratização do país. Algumas conquistas, como a nova constituição federal e o final da censura hão de ser louvadas, mesmo porque boa parte das canções aqui inseridas não poderiam ter sido veiculadas sob o jugo militar, bem como os cartuns e tiras de Angeli, que se valeram da liberdade recém conquistada para fazer rir seus leitores. Porém, não nos esqueçamos dos péssimos planos econômicos, que geravam inflação crescente a cada dia e deixavam a vida da população cada vez mais complicada e penosa.

Enfim, este trabalho consistiu em traçar um paralelo entre as ações governamentais e as produções da Indústria Cultural, para demonstrar como o povo brasileiro, e principalmente o jovem, reagia frente aos desmandos do governo, quais suas indignações e qual a forma de fazer humor nesta nova configuração social. E acreditamos que as duas maiores forças da cultura de massa que representavam o jovem do período e suas ideias foram as canções do rock nacional, e a verve crítica das tiras e charges de Arnaldo Angeli Filho.

\section{Fontes}

ANGELI. Chiclete com Banana no 1. São Paulo: Circo, 1985. p.5

ANGELI. Chiclete com Banana no 6. São Paulo: Circo, 1986. p.17

ANGELI. Chiclete com Banana no 11. São Paulo: Circo, 1987. p.23

ANGELI. Chiclete com Banana no 13. São Paulo: Circo, 1988. p.4

ANTUNES, Arnaldo; MELLO, Branco (1987). Dívidas. Em Cabeça Dinossauro [LP]. São Paulo: WEA 
GAVIN, Charles; FROMER, Marcelo; BRITTO, Sérgio. (1987). Desordem. Em Jesus não tem dentes no país dos banguelas [LP]. Rio de Janeiro: WEA Records.

HUMMEL, Karl; NOVA, Marcelo (1986). Solução Final. Em Viva! [LP]. Rio de Janeiro: RGE Records.

JAIME, Léo; ABREU, Selvagem Big (1985). O Regime. Em Sessão da Tarde [LP]. Rio de Janeiro: Epic Records.

NEVES, Ezequiel; FREJAT, Roberto; GOFFI, Guto (1986). Declare Guerra. Em Declare Guerra [LP]. Rio de Janeiro: Som Livre

RIBEIRO, Bi; VIANNA, Hebert; BARONE, João (1986). Selvagem. Em Selvagem [LP]. Rio de Janeiro: EMI Records.

SANTANNA, Rogério; NOVA, Marcelo (1987). País do Futuro. Em Duplo Sentido [LP]. Rio de Janeiro: WEA Records.

RUSSO, Renato (1987). Que país é este?. Em Que país é este [LP]. Rio de Janeiro: EMI Records.

VILHENA, Bernardo; Lobão (1988). O eleito. Em Cuidado! [LP]. Rio de Janeiro: RCA Records.

\section{Referências bibliográficas}

ARIDA, Pérsio e LARA RESENDE, André. Inflação Inercial e reforma Monetária. In; Arida, Pérsio (org). Inflação Zero: Brasil, Argentina e Israel. Rio de Janeiro: Paz e Terra, 1986

DÓRIA, Palmério. Honoráveis Bandidos: Um retrato do Brasil na era Sarney. São Paulo: Geração Editorial, 2012.

DREIFUSS, René. O Jogo da Direita. São Paulo: Vozes, 1989.

LEITÃO, Miriam. A Saga Brasileira. Rio de Janeiro: Record, 2010

MALDITOS CARTUNISTAS. Direção, Edição e Produção: GARCIA, Daniel \& PAIVA, Daniel. Brasil: Daniéis Entretenimento, 2011

MORAES, Pedro Bodin de. Política monetária e oferta de crédito durante o Plano Cruzado. In: Revista Brasileira de economia v.44 nº 1. Jan/mar 1990.

PIlagallo, Oscar. A história do Brasil no século XX: (1980/200o). São Paulo: Publifolha, 2006.

SKIDMORE, Thomas. Brasil: de Castelo a Tancredo. Rio de Janeiro: Paz e Terra, 1988 
Revista Brasileira de História \& Ciências Sociais - RBHCS

Vol. $8 \mathrm{~N}^{\mathrm{O}}$ 16, Julho - Dezembro de 2016

STEFANELLI, Roberto. História da Inflação no Brasil. Brasil: TV Câmara, 2002

SOLA, Lourdes. Estado, Regime Fiscal e Ordem Monetária: Qual Estado? In: SOLA, Lourdes \& PAULANI, Leda M. Lições da década de 80. São Paulo: Edusp, 1995 .

SOUZA, Maria do Carmo Campello de. A Nova República Brasileira: sob a espada de Dâmocles.in: STEPAN, Alfred (org). Democratizando o Brasil. Rio de Janeiro, Paz e Terra: 1988.

VERGUEIRO, Waldomiro. Chiclete com Banana abrindo os caminhos. in: MENDES, Toninho (org.). Humor Paulistano - A experiência da Circo editorial (1984-1995). São Paulo: SESI, 2014.

Recebido em Maio de 2016 Aprovado em Novembro de 2016 